\title{
Brief Mindfulness Meditation Based Stress Reduction Programme in Controlling Examination Anxiety of Secondary School Students
}

\author{
Arjunan, N. $\mathrm{K}^{1 *}$, Joxy Joseph ${ }^{1}$
}

Keywords: Meditation, Stress, Reduction Programme, Examination, Anxiety, Secondary School, Student

The relationship between anxiety and impaired academic performance has been well documented by a number of investigators (Tyron, 1980; Hill \& Wigfield, 1984; Topp, 1989; Sud \& Sharma, 1990; Zeidner, 1990; Zoller \& Ben-chain, 1990). Everyone should feel somewhat anxious before they begin to take a test. Anxiety becomes a problem when it begins to interfere with a student's ability to think logically or remember facts. Examination anxiety (test-anxiety) is a common and frequently debilitating condition characterized by intense fear of evaluation in performance situations (Jefferys, 1997). It has an early onset (Otto et al., 2001) and regularly precedes other anxiety, mood, and substance dependence disorders (Lampe et al.,. 2003). Examination anxiety is associated with significant distress and functional impairment in both work and social domains (Lochner et al., 2003) and typically persists unless treated (Clark \& Wells, 1995). The early onset of test-anxiety .magnifies its impact, including increased school dropout (Van Ameringen et al., 2003), poor social integration, and increased comorbid psychopathology (Lampe et al., 2003).

Mindfulness meditation is one of the most widely known clinical programs designed to give instruction and experience in mindfulness practice, as well as guidance and suggestion in integrating mindfulness into everyday life to facilitate increased well-being and reductions in psychological distress. Recently, mindfulness-based interventions have been of increasing interest as a cost-effective, low-stigma, accessible treatment option for a variety of psychological and medical symptoms, including anxiety (Hofmann et al., 2010). Mindfulness training teaches participants meditation techniques that increase awareness of present-moment experiences, including thoughts, emotions, and bodily sensations, with a gentle and accepting attitude towards oneself (Bishop et al., 2004). Roemer et al (2009) found that patients with general anxiety have

\footnotetext{
${ }^{1}$ CUTEC, JMC, University of Calicut, Aranattukara.P.O., Thrissur, Kerala

*Responding Author

(C) 2016 I N Arjunan, J Joseph; licensee IJIP. This is an Open Access Research distributed under the terms of the Creative Commons Attribution License (http://creativecommons.org/licenses/by/2.0), which permits unrestricted use, distribution, and reproduction in any Medium, provided the original work is properly cited.
} 


\section{Brief Mindfulness Meditation Based Stress Reduction Programme in Controlling Examination Anxiety of Secondary School Students}

lower levels of trait mindfulness and more difficulties with emotion regulation than healthy controls and suggested that mindfulness training may be helpful.

Whereas no previous study has examined the effects of a brief mindfulness intervention on examination anxiety and subsequent academic performance, extensive research suggests that mindfulness interventions are effective at reducing anxiety and stress as well as benefitting working memory capacity (Weger et al, 2012) and executive control (Teper \& Inzlicht, 2012). The investigatorS thus hypothesize that mindfulness meditation represents a potentially promising approach to reducing examination anxiety and increasing academic achievement. To date, however, there has been little work on how mindful meditation is effective in mitigating examination anxiety among secondary school students in the context of their achievement, and hence the rationale of this study.

\section{Objectives}

This present study aims to investigate the effect of doing mindfulness meditation on examination anxiety. The study has the following specific objectives in view:

1. To find out the examination anxiety of control and experimental group before practicing mindfulness meditation.

2. To find out the level of examination anxiety of the control and experimental group after practicing mindfulness meditation.

3. To find out the effect of mindfulness meditation on examination anxiety of the experimental group in comparison to the control group.

4. To find out the effect of mindfulness meditation on examination anxiety of student in high-, average-, and low achievement levels.

\section{Hypotheses}

They study has the following hypotheses in view:

$\mathrm{H}_{1}$ : There will be no significant difference between the mean pre-test examination anxiety scores of control group and experimental group.

$\mathrm{H}_{2}$ : There will be no significant difference between the mean pre-test scores and mean post-test scores of examination anxiety in control group.

$\mathrm{H}_{3}$ : There will be a significant difference between the mean pre-test scores and mean post-test scores of examination anxiety in experimental group.

$\mathrm{H}_{4}$ : There will be a significant difference between the mean post-test examination anxiety scores of control group and experimental group.

$\mathrm{H}_{5}$ : There will be no significant difference between mean pre-test and post-test scores of examination anxiety in high-, average-, and low achievers in secondary schools.

$\mathrm{H}_{6}$ : There will not be any significant difference among students in the high-, average-, and low achievement levels with regard to their post-test scores. 


\section{METHODOLOGY}

The study followed a pretest-posttest control group design by taking examination anxiety as dependent variables, mindfulness meditation as independent variable, and achievement level as classificatory variable. The population for the study is the secondary school students in the age range 13-15, studying in the secondary schools of Kerala. A non-probability sample of 80 students, selected conveniently, constituted the sample for the experimental study. The data pertained to examination anxiety was collected by administering the Test-Anxiety Scale for Secondary School Students (TASS) developed by Arjunan \& Francis (2009) and the scores of mid-term examination, measured and maintained by the school authorities as a part of comprehensive evaluation, constituted the secondary data for the purpose of classifying subjects into different levels of achievement. The Brief Mindfulness-Based Stress Reduction Programme (BMBSRP), modeled on the Mindfulness-Based Stress Reduction (MBSR) program developed by Kabat-Zinn et al (2003), constituted the intervention programme for alleviating examination anxiety of the experimental group. The data thus collected were subjected to both descriptive and inferential statistical analysis with the help of SPSS (for Windows 16.0).

\section{RESULTS AND DISCUSSION}

The details of the analysis done with respect to each of the objectives are presented below:

\section{Comparison of pre-test TASS Scores: Experimental and Control Groups}

The details regarding the data and results of comparison between pre-test TASS scores of experimental group and control group are given in Table 1.

Table1: Comparison of Mean Examination Anxiety Scores of Experimental and Control Groups (Pre-test Scores)

\begin{tabular}{|l|l|l|l|l|l|}
\hline $\begin{array}{l}\text { Treatment } \\
\text { Groups }\end{array}$ & Size (N) & $\begin{array}{l}\text { Mean } \\
(\mathbf{M})\end{array}$ & $\begin{array}{l}\text { Standard } \\
\text { Deviation } \\
(\boldsymbol{\sigma})\end{array}$ & t-value & $\begin{array}{l}\text { Level of } \\
\text { Significance }\end{array}$ \\
\hline $\begin{array}{l}\text { Experimental } \\
\text { Group }\end{array}$ & 44 & 155.82 & 34.47 & 0.31 & Not Significant \\
\hline $\begin{array}{l}\text { Control } \\
\text { Group }\end{array}$ & 44 & 153.70 & 28.42 & & \\
\hline
\end{tabular}

Statistical analysis of the data (Table 1$)$ revealed that, there is no significant difference $(t=0.31$; $\mathrm{P}>0.05$ ) between Experimental and Control group with regard to their pre-test examination anxiety scores. Hence hypothesis formulated in this context viz., H1: There will be no significant difference between the mean pre-test examination anxiety scores of control group and experimental group) is accepted. 


\section{Comparison of Pre-test and Post-test TASSScores: Control Group}

The data and results of the comparison between pre-test and post-test Examination Anxiety Scores of the Control Group are given in Table 2.

Table 2: Comparison of Mean Pre-test and Post-test Examination Anxiety Scores of Control Group (Paired t-test)

\begin{tabular}{|c|c|c|c|c|c|}
\hline Groups & Size $(\mathbf{N})$ & $\begin{array}{l}\text { Mean } \\
(\mathbf{M})\end{array}$ & $\begin{array}{l}\text { Standard } \\
\text { Deviation ( } \sigma)\end{array}$ & t-value & $\begin{array}{l}\text { Level of } \\
\text { Significance }\end{array}$ \\
\hline $\begin{array}{l}\text { Control group } \\
\text { Pre-test }\end{array}$ & 44 & 153.70 & 28.417 & \multirow{2}{*}{1.59} & \multirow{2}{*}{ Not Significant } \\
\hline $\begin{array}{ll}\text { Control group } \\
\text { Post-test }\end{array}$ & 44 & 153.50 & 28.219 & & \\
\hline
\end{tabular}

The result of the paired-samples t-test given in Table 2 shows that there is no significant difference ( $\mathrm{t}=1.59 ; \mathrm{P}>0.05$ ) between the mean pre-test and post-test examination anxiety scores of the control group. Hence hypothesis formulated in this context viz., $\mathrm{H}_{2}$ : there will be no significant difference between the mean pre-test scores and mean post-test scores of examination anxiety in control group is accepted.

\section{Comparison of the Pre-test and Post-test TASS Scores: Experimental Group}

To find out whether the Brief Mindfulness-Based Stress Reduction Programme was effective in reducing examination anxiety in secondary school students, the mean examination anxiety scores of the group before and after the experimental intervention were compared by applying paired samples t-test. The data and results of the comparison made in this context are given in Table 3.

Table 3: Comparison of Mean Pre-test and Post-test Examination Anxiety Scores of Experimental Group (Paired t-test)

\begin{tabular}{|l|l|l|l|l|l|}
\hline Groups & Size (N) & $\begin{array}{l}\text { Mean } \\
(\mathbf{M})\end{array}$ & $\begin{array}{l}\text { Standard } \\
\text { Deviation } \\
(\boldsymbol{\sigma})\end{array}$ & t-value & $\begin{array}{l}\text { Level of } \\
\text { Significance }\end{array}$ \\
\hline $\begin{array}{l}\text { Experimental group } \\
\text { Pre-test }\end{array}$ & 44 & 153.55 & 28.627 & 3.75 & $\begin{array}{l}\text { Significant at } \\
0.01 \text { level }\end{array}$ \\
\hline $\begin{array}{l}\text { Experimental group } \\
\text { Post-test }\end{array}$ & 44 & 144.95 & 33.744 & \\
\hline
\end{tabular}




\section{Brief Mindfulness Meditation Based Stress Reduction Programme in Controlling Examination Anxiety of Secondary School Students}

The t-value obtained on comparing the pre-test and post-test TASS scores of experimental group is significant ( $\mathrm{t}=3.75 ; \mathrm{p}<0.01$ ), showing that there exist a true difference between the examination anxiety of the group before and after the experimental intervention. Hence hypothesis formulated in this context viz., $\mathrm{H}_{3}$ : there will be a significant difference between the mean pre-test scores and mean post-test scores of examination anxiety in experimental group, is accepted.

\section{Comparison of the Post-test Examination Anxiety Scores of Control Group and Experimental Group}

The extent to which the Brief Mindfulness-Based Stress Reduction Programme is effective in alleviating the examination anxiety of secondary school students could be assessed accurately only by comparing the post-test scores of control group and experimental group. The data and result of the analysis carried out in this context is given in Table 4.

Table 4: Comparison of Mean Post-test Scores of Control Group and Experimental Group (Independent Samples t-test)

\begin{tabular}{|l|l|l|l|l|l|}
\hline Groups & Size (N) & $\begin{array}{l}\text { Mean } \\
(\mathbf{M})\end{array}$ & $\begin{array}{l}\text { Standard } \\
\text { Deviation } \\
(\boldsymbol{\sigma})\end{array}$ & t-value & $\begin{array}{l}\text { Level } \\
\text { Significance }\end{array}$ \\
\hline $\begin{array}{l}\text { Control group Post- } \\
\text { test }\end{array}$ & 44 & 153.50 & 28.219 & 2.91 & $\begin{array}{l}\text { Significant at } \\
0.01 \text { level }\end{array}$ \\
\hline $\begin{array}{l}\text { Experimental group } \\
\text { Post-test }\end{array}$ & 44 & 136.69 & 26.163 & \\
\hline
\end{tabular}

The t-value obtained on comparing the post-test scores of control group and experimental group is significant $(\mathrm{t}=2.91 ; \mathrm{p}<0.01)$ showing the presence of a real difference between the groups. Scrutiny of the data presented in Table 4 indicates that the mean examination anxiety scores for the experimental group is significantly lower than that in the control group. This difference between the post-test scores of control group and experimental group could be attributed to the effectiveness of Brief Mindfulness-Based Stress Reduction Programme. In the light of the above finding, the hypothesis $\mathrm{H}_{4}$ : there will be a significant difference between the mean post-test examination anxiety scores of control group and experimental group is accepted. 
Comparison of the Pre-test and Post-test TASS Scores of Students in differentAchievement Levels in the Experimental Group

The pre-test and post-test examination anxiety scores of students in different levels of achievement are compared to test the significance of difference between the means. The details of the paired t-test carried out in this are given in Table 5.

Table 5: Comparison of Mean Pre-test and Post-test Examination Anxiety Scores of Students in different Levels of Achievement in Experimental Group (Paired t-test)

\begin{tabular}{|c|c|c|c|c|c|c|}
\hline $\begin{array}{l}\text { Achievement } \\
\text { Levels }\end{array}$ & Test Groups & $\begin{array}{l}\text { Size } \\
(\mathrm{N})\end{array}$ & $\begin{array}{l}\text { Mean } \\
(\mathbf{M})\end{array}$ & 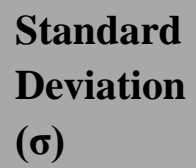 & t-value & $\begin{array}{l}\text { Level of } \\
\text { Significance }\end{array}$ \\
\hline \multirow{2}{*}{ High } & $\begin{array}{l}\text { Pre-BMBSRP } \\
\text { Group }\end{array}$ & 9 & 136.00 & 27.445 & \multirow{2}{*}{5.39} & \multirow{2}{*}{$\begin{array}{l}\text { Significant } \\
\text { at } 0.01 \text { level }\end{array}$} \\
\hline & $\begin{array}{l}\text { Post-BMBSRP } \\
\text { Group }\end{array}$ & 9 & 129.22 & 26.485 & & \\
\hline \multirow{2}{*}{ Average } & $\begin{array}{l}\text { Pre-BMBSRP } \\
\text { Group }\end{array}$ & 25 & 157.48 & 26.866 & \multirow{2}{*}{6.24} & \multirow{2}{*}{$\begin{array}{l}\text { Significant } \\
\text { at } 0.01 \text { level }\end{array}$} \\
\hline & $\begin{array}{l}\text { Post-BMBSRP } \\
\text { Group }\end{array}$ & 25 & 151.04 & 26.420 & & \\
\hline \multirow{2}{*}{ Low } & $\begin{array}{l}\text { Pre-BMBSRP } \\
\text { Group }\end{array}$ & 10 & 159.50 & 30.511 & \multirow{2}{*}{5.75} & \multirow{2}{*}{$\begin{array}{l}\text { Significant } \\
\text { at 0.01level }\end{array}$} \\
\hline & $\begin{array}{l}\text { Post-BMBSRP } \\
\text { Group }\end{array}$ & 10 & 151.50 & 27.456 & & \\
\hline
\end{tabular}

The t-values obtained on comparing the Pre-test and Post-test TASS scores of the the experimental group in all the three levels of achievement are significant showing that the BMBSRP intervention is effective for reducing the test-anxiety of all kinds of achievers in the classroom. The hypothesis formulated in this context viz., $\mathrm{H}_{5}$ : there will be no significant difference between mean pre-test and post-test scores of examination anxiety in high-, average-, and low achievers in secondary schools, is rejected.

Comparison of the Post-test Scores of High-, Average-, and Low Achievers in the Experimental Group

The differential effect of the experimental intervention up on the post-test scores of students in different levels of achievement was studied by comparing the mean scores. One way ANOVA was done with the help of SPSS to find out significant differences, in any, among the groups compared. The data and result of the analysis carried out in this context is given below in Table 6. 
Table 6: Comparison of Mean Post-test Scores of Examination Anxiety for High-, Average-, and Low Achievers (Result of ANOVA)

\begin{tabular}{|l|l|l|l|l|l|}
\hline ANOVA & Sum of Squares & df & Mean Square & F & Sig. \\
\hline Post-test & 3726.312 & 2 & 1863.156 & & \\
\hline Wetween Groups & 30417.416 & 41 & 741.888 & 2.511 & .094 \\
\hline Total & 34143.727 & 43 & & & \\
\hline
\end{tabular}

The result of One way ANOVA, given in Table 6, shows that the F-value obtained is not significant $(\mathrm{F}=2.511 ; \mathrm{p}>0.01)$, revealing the fact that the groups compared do not differ significantly with regard to their post-test scores. To state in another words, the high-, average and low-achievers are almost alike in their examination anxiety after the experimental intervention. The hypothesis $\mathrm{H}_{6}$ : there will be significant difference among students in the high-, average-, and low achievement levels with regard to their post-test scores, is hence rejected.

\section{CONCLUSIONS}

The following are the major findings emerged from the analysis

1. The control group and experimental group are alike with regard to the pre-test scores of examination anxiety.

2. The control condition does not bring about any change in the examination anxiety of secondary school students.

3. There is significant difference between the pre-test and post-test examination anxiety scores of the experimental group. The post-test mean test-anxiety scores are lower than the pre-test mean test-anxiety scores. The experimental intervention brought about significant reduction in the examination anxiety of students in the experimental group.

4. Comparison of the experimental and control group revealed that there is significant difference between the two groups in terms of the mean post-test scores and that the experimental group is superior to control group. The Brief Mindfulness-Based Stress Reduction Programme is effective in bringing down the examination anxiety of secondary school students.

5. There exist significant differences between the pre-treatment and post-treatment mean scores of examination anxiety for all the three levels of achievement in the experimental group. The stress reduction programme introduced was effective in lessening the examination anxiety of all kinds of achievers in secondary schools. 


\section{REFERENCES}

Arjunan, N. K., \& Francis, R. (2009).Test-anxiety scale for secondary school students. Coimbatore: Bharathi College of Education.

Bishop, S. R. B., Lau, M., \& Shapiro, S. (2004). Mindfulness: A proposed operational definition. Clinical Psychology: Science and Practice, 11(3): 230-241.

Clark, D. M., \& Wells, A. (1995). A cognitive model of social phobia. New York: Guilford Press.

Hill, K. T., \& Wigfield, A. (1984). Text-anxiety: A major educational problem and what can be done about it. Elementary School Journal, 85: 105-126

Hofmann, S. G., Sawyer, S. G., \& Wilt, A . A. (2010). The effect of mindfulness-based therapy on anxiety and depression: a meta-analytic review. J Consult Clin Psychol., 78(2):16983.

Jefferys, D. (1997). Social phobia: The most common anxiety disorder. Australian Family Physician, 26 (1061), 1064-1067.

Kabat-Zinn, J. (2003). Mindfulness-based interventions in context: Past, present, and future. Clinical Psychology: Science and Practice, 10(2), 144-156.

Lampe, L., Slade, T., Issakidis, C., \& Andrews, G. (2003).Social phobia in the Australian National Survey of Mental Health and Well-Being (NSMHWB).Psychological Medicine, 33: 637-646.

Otto, M. W., Pollack, M. H., Maki, K. M., Gould, R. A., Worthington, J. J., III, Smoller, J. W. (2001). Childhood history of anxiety disorders among adults with social phobia: Rates, correlates, and comparisons with patients with panic disorder. Depression and Anxiety, 14: 209-213.

Roemer, L., Lee, J. K., Salters-Pedneault, K, Erisman, S. M, Orsillo, S. M, \&Mennin, D. S. (2009). Mindfulness and emotion regulation difficulties in generalized anxiety disorder: Preliminary evidence for independent and overlapping contributions. Behavioural Therapy, 40(2):142-154.

Sud, A. \& Sharma, S. (1990). Examination stress and test anxiety: A cross cultural perspective. Psyc. Dev. Soc.: 183-201.

Teper, R. \&Inzlicht, M. (2012). Meditation, mindfulness and executing control: The importance of emotional acceptance and brain-based performance monitoring. Social Cognitive and Affective Neuroscience Advance Access, doi:10.1093/scan/nss045.

Topp, R. (1989). Effect of relaxation or exercise on undergraduates' test anxiety. Perceptual and Motor Skills, 69(1): 35-34.

Tyron, G. (1980). The measurement and treatment of test anxiety. Educational Research Review, 50: 343-372.

Van Ameringen, M., Mancini, C., \& Farvolden, P. (2003). The impact of anxiety disorders on educational achievement. Journal of Anxiety Disorders, 17: 561-571. 
Weger, U., Hooper, N., Meier, B., Hopthrow, T. (2012). Mindful maths: Reducing the impact of stereotype threat through a mindfulness exercise. Consciousness and Cognition, 21: 471475.

Zeidner, M. (1990). Does test anxiety bias scholastic aptitude test performance by gender and socio-cultural group? Journal of Personality Assessment, 55: 145-160.

Zoller, U., \& Ben-Chain, D. (1990). Gender differences in examination type, test anxiety, and academic achievement in college science: a case study. Science Education, 74(6): 597608. 